\title{
DEVELOPMENT E-PORTFOLIO AS A MODEL OF AUTHENTIC ASSESSMENT
}

\author{
Lamberthus J. Lokollo ${ }^{1}$ and J. L. Kundre ${ }^{1}$ \\ ${ }^{1}$ Faculty of Teacher Training and Educational Sciences - Pattimura University - Maluku- \\ Indonesia \\ (1ambertuslokollo@gmail.com)
}

\begin{abstract}
Authentic assessment is an essential component of effective learning that links theory to practice. As information technology has developed, portfolios have been considered authentic environments to enable learning students to reflect their potential through the evidence presented in the e-portfolio. This research's general objective is to produce an e-portfolio based authentic assessment model for the PNFI Learning Media Development course in the Non-formal Education Study Program, Faculty of Teacher Training and Education, Universitas Pattimura. The method used in this research is the development research method. It uses three main stages of the Tjeer Plomp model: 1) preliminary research, 2) prototype design and development and expert validation, and 3) testing and revision. This study involved 71 students of the Faculty of Teacher Training and Education, Universitas Pattimura and three experts in assessment, media, and learning technology. The research data were obtained through interviews, questionnaires and observations. This study found that Mahara is a suitable platform to be used in the learning process and is recommended to be developed as an e-portfolio based authentic learning model in the Non-formal Education Study Program, Faculty of Teacher Training and Education, Universitas Pattimura.
\end{abstract}

Keywords: authentic assessment, e-portfolio, mahara

\section{Introduction}

The revolution in the field of learning assessment in the last two decades has given birth to new paradigms in learning assessment, including: alternative assessment, authentic assessment, performance assessment, and portfolio assessment (portfolio assessment). The need for this alternative assessment model to be based on the assessment model that has been relied on paper-pencil tests drills are considered to only evaluate performance and do not fully describe the knowledge and competence of students (Smith, Schalkwyk and D'Amato, 2012: 81). Whereas students should be given enough opportunities to demonstrate cognitive and academic skills and understanding through various methods, such as portfolios, discussions, presentations, or projects as a companion to traditional testbased assessment models.

Assessment is an integral part of teaching and learning actions and is fundamentally an important component for the entire educational process, because it can be used to support student development, and the findings can be applied to establish educational goals and objectives. Based on the information collected, either through written tests, or in the form of assignments to make papers or written reports, the lecturer uses the assessment results data to identify learning difficulties and monitor student learning progress, to further make decisions to make improvements related to course plans including: management class, the next learning activity.

Indonesian National Higher Education Standards requires the principles of assessment in higher education which include educational, authentic, objective, accountable, transparent and carried out in an integrated manner. The assessment must cover both the

Received December $17^{\text {th }} 2020$, Revision January $27^{\text {th }} 2021$, Accepted for publication February $24^{\text {th }} 2021$. Copyright (C) 2021 Published by FKIP - Unpatti, ISSN 2721-3110 
process and student learning outcomes using a combination of various assessment techniques, including observation, participation, performance, written tests, oral tests, and questionnaires as well as assessment instruments consisting of process assessments in the form of rubrics and / or assessment of results in the form of a portfolio or design work.

Thus, it is not sufficient to assess student learning processes and outcomes only in the form of paper-and-pencil tests commonly used and has been going on for a long time and has a long history in assessing student performance. criterion-referenced test and norm referenced test that uses traditional assessment tools such as tests, quizzes, and paper is not sufficient to describe the real abilities of students, because tend to focus too much on memorizing and retaining conceptual knowledge and understanding (Russell III, Waters, and Turner, 2014: 79). While Positive features of the assessment may be achieved through performance tests or portfolios which can facilitate a more authentic and form of assessment. a broader assessment strategy that is results-based and provides students with greater choice in how they meet program learning requirements. Evidence collected in a portfolio can provide a richer picture of the strengths and achievements of students. In addition, for some students, assessments with portfolios were not as scary as assessments carried out traditionally.

The importance of an authentic assessment model that is fair and objective and based on the performance of students and can reflect their potential through the evidence presented in this e-portfolio is a strong reason to develop. e-portfolio based authentic assessment model for lectures in the Non-formal Education Study Program, Faculty of Teacher Training and Education, Universitas Pattimura.

\section{Theoretical Framework}

Authentic assessment is normally interpreted as an alternative form of assessment involve learners in real world tasks. Authentic assessments are also often referred to as performance assessments or alternative assessments. The alternative term is used to describe this assessment as an alternative to a multiple-choice or short-answer test. Meanwhile, it is called authentic, because this assessment allows students to show what they can do in real situations (Russel and Airaisian, 2012: 202).In the performance appraisal or authentic assessment, students are not asked to show their knowledge by choosing or explaining something. In contrast, this assessment gives students tasks with certain criteria that require them to apply certain skills or knowledge to complete them.

Thus the modelappraisalauthentic is not designed as a substitute, but is an alternative that can be combined with traditional assessment models to measure student performance. According to, Lisa M Beck and Thomas Hatch (in Clauss-Ehlers, 2010: 135), pen authentic assessment is designed to encourage students to perform assignments they might find in the real world; encourage students to generate knowledge and involve them in the process of inquiry; increase understanding in depth to solve problems, and use a variety of skills and knowledge, provide opportunities for them to revise and improve their performance, and involve them to actively participate in evaluating performance, and the development of the learning process. This assessment can be conducted and implemented in various formats and ways, including through portfolios, journals, debates, and research projects.

Assessmentauthenticity can enhance learning in many important ways. Johnson (2002: 166) identifies several advantages of this authentic assessment, among others, it can encourage students to: (a) fully disclose how well they have understood academic material, (b) improve information gathering skills, use various resources and technology, and think systemically., (c) linking learning with their own experiences, their own world, and the larger society, (d) sharpening higher thinking abilities as they analyze, synthesize, identify problems, create solutions, and connect causality, (e) ) accept responsibility and make choices, (f) collaborate in carrying out tasks, and (g) learn to self-evaluate one's own performance (Newmann \& Wehlage,

Received December $17^{\text {th }} 2020$, Revision January $27^{\text {th }} 2021$, Accepted for publication February $24^{\text {th }} 2021$. Copyright (C) 2021 Published by FKIP - Unpatti, ISSN 2721-3110 
The word portfolio comes from the Italian "portare fogliou" which means "to carry paper" and has been used widely in various professions, such as art, photography, architecture and music for decades (Rassin et.a. in Timmins, $2008: 22$ ). WhileMarianne Jones and Marilyn Shelton (2011: 21-22) defines a portfolio as:

A rich, contextual and highly personal document of a person's learning journey that deliberately contains documentation that clearly demonstrates knowledge of specific skills, dispositions and accomplishments attained over time. Portfolios represent the relationships created between actions and beliefs, thoughts of action, evidence and criteria and serve as media for reflection through constructing meaning, making the learning process more visible, crystallizing insights, and anticipating future directions.

Along with the development of information and communication technology so that many literatures can find various terminologies regarding the development of the concept of portfolios, among others, electronic portfolios, ePortfolios, e-portfolios, efolios, digital portfolios, webfolios, web-based portfolios, online portfolios, and so on, which according to Nicole Buzzetto-More (2010: 112) e-portfolios are:

A collection of selected and structured information that is collected for a specific purpose and shows / proves the achievement and progress of a person that is digitally stored and managed using the right software and developed using appropriate multimedia and is usually in the web environment and can be obtained through the website or delivered using CD-ROM or DVD.

Based on the definition above, portfolio digitization allows document formats such as text, graphics, images, sound, and animation to all be connected via a LAN (Local Area Network) or WAN (Wide Area Network) in the form of multimedia and software such as database management systems. used to set and combine boundaries not possible in traditional portfolio learning formats.

The results of various studies indicate that in addition to helping students to develop critical and reflective thinking, the use of e-portfolios can be an authentic assessment tool that can provide benefits on a larger scale. Research Buyarski and Landis (2014), found that e-portfolios are a rich source of authentic evidence in learning assessment. This evidence is related to the rubric score which shows the insight and depth of students' level of thinking related to certain topics including self-understanding. While the research resultsHsleh, Lee, Chen (2015), found thatStudents need to be encouraged to develop eportfolios because it is useful for increasing self-reflection and evaluation which facilitates their preparation for future work. This research also recommends the need to consider the right technology system to start with for e-portfolios, such as the use of mobile phonebased applications that can motivate students to actively develop e-portfolios for lifelong learning.

Assessment with e-portfolios is generally used in situations where students are not tested or assessed in conventional ways. In this assessment model students prove their competence in certain fields of study by providing photos, recording findings via video, or reflective reports. Authentic assessment with e-portfolio fits perfectly with the idea of learning and authentic assessment where the assessment must be based on the performance of students, as this relates to their potential. Evidence of student performance can be presented in an e-portfolio where students choose their own work to be presented based on self-evaluation.

Sufeng Yan, Runjuan Song, and Liming Sun in Jia Luo (2012: 757-758)identify 3 (three) advantages of the use of e-portfolios, including:

Received December $17^{\text {th }} 2020$, Revision January $27^{\text {th }} 2021$, Accepted for publication February $24^{\text {th }} 2021$.

Copyright (C) 2021 Published by FKIP - Unpatti, ISSN 2721-3110 
First, the main content of the portfolio is the work of the participants. In contrast to the traditional way of assessment, e-portfolio based assessments pressure students to collect various types of work from their daily learning. Through the materials collected the teacher will get authentic information about the achievement and learning progress of students. In addition, E-portfolio also documents students' learning processes and strategies and can show their emotional status and attitudes.

Second, collections of learners' work were deliberately developed If the purpose of building a portfolio is to demonstrate student achievement, the best and most important documents should be included. However, if it is intended to record the learning development of students, materials related to learning activities must be included. This will make it easier for teachers to find improvements in their learning. By comparing different portfolios it will be clearer to see the increase in students from various aspects.

Third, Traditional, assessment places too much emphasis on classification and selection and learning outcomes. This results in excessive emphasis on test scores. Eportfolio collects data generated during the learning process. especially regarding the learning process, learning strategies, weaknesses and developmental strengths of participants, so that teachers can provide suggestions to help students after analyzing the data they have collected.

Based on the description above, this study aims to produce a model e-portfolio based authentic assessment for the the Non-formal Education Study Program, Faculty of Teacher Training and Education, Universitas Pattimura.

\section{Method}

The method used in this research is development research, which according to Seels \& Richey (1994: 137) is a "systematic study of the design, development and evaluation of programs, processes and products that must meet the criteria of internal consistency and effectiveness. Thus, development studies are a process used to develop and validate educational products whose main stages include analysis, design and development as well as evaluation and revision. Referring to the three main stages of the development design proposed by Tjeer Plomp (2013: 16), the development of an E-Portfolio-Based Assessment Model for the Non-formal Education Study Program, Faculty of Teacher Training and Education, Universitas Pattimura consists of three main stages, namely as follows:

1) Preliminary research, including needs and context analysis, literature review, and the development of a conceptual or theoretical framework to produce a conceptual model and a procedural model for developing an e-portfolio based assessment model. This stage includes an in-depth literature review regarding the concept of an e-portfoliobased authentic assessment model, conducting an analysis of similar models that have been developed before, examining the strengths and weaknesses of each to then decide whether the models to be developed are the same model. once new or modify and improve existing models. At this stage, a field study was also carried out in the form of observation and data collection regarding the gaps in the ongoing assessment model and the availability of facilities and infrastructure and resources that could support the development of an e-portfolio-based authentic assessment model. To achieve this goal, interview, questionnaire and observation techniques will be used.

2) The design and development stage or the construction of a prototype which consists of design and development steps. The design step aims to produce a blueprint for an eportfolio based authentic assessment model, while in the development step a prototype will be produced in the form of an application and guidelines for implementing an eportfolio based authentic assessment.

Received December $17^{\text {th }} 2020$, Revision January $27^{\text {th }} 2021$, Accepted for publication February $24^{\text {th }} 2021$. Copyright (C) 2021 Published by FKIP - Unpatti, ISSN 2721-3110 
3) The validation, trial and revision stages, namely conducting field testing in the setting in which it will be used, and revising it to correct deficiencies found in the testing phase, until field test data shows the product meets the stated objectives. Validation will be carried out by content experts, assessment experts and media experts. While the trials are carried out through formative evaluation, which consists of one-on-one tests, small group tests, field tests. Revisions are made based on input from experts and trial results. To achieve this goal, interview techniques, questionnaires and observations will be used.

\section{Results and Discussion}

At this stage, a survey was conducted of 71 students related to fulfilling the principles of learning assessment that had been carried out so far. The results of this survey can be seen in table 1.

Table 1 Fulfilment of assessment principles in learning assessment in the Non-formal Education Study Program

\begin{tabular}{|c|c|c|}
\hline Implementation of the Assessment & $\begin{array}{l}\text { Average } \\
\text { Score }\end{array}$ & Criteria \\
\hline $\begin{array}{l}\text { 1. Learning assessments by lecturers motivate students to } \\
\text { be able to improve student learning methods }\end{array}$ & 3.85 & Good \\
\hline $\begin{array}{l}\text { 2. Learning assessments by lecturers motivate students to } \\
\text { be able to achieve learning outcomes. }\end{array}$ & 4.01 & Good \\
\hline $\begin{array}{l}\text { 3. Learning assessment by lecturers is oriented towards } \\
\text { continuous learning }\end{array}$ & 3.55 & Good \\
\hline $\begin{array}{l}\text { 4. The learning assessment by the lecturer reflects the } \\
\text { student's ability during the learning process }\end{array}$ & 3.75 & Good \\
\hline $\begin{array}{l}\text { 5. Learning assessments by lecturers are based on } \\
\text { standards agreed upon between lecturers and students }\end{array}$ & 4.03 & Good \\
\hline $\begin{array}{l}\text { 6. Learning assessment by lecturers is free from the } \\
\text { influence of subjectivity }\end{array}$ & 3.46 & Good \\
\hline $\begin{array}{l}\text { 7. The learning assessment by the lecturer is in } \\
\text { accordance with clear procedures and criteria }\end{array}$ & 3.75 & Good \\
\hline $\begin{array}{l}\text { 8. Learning assessments by lecturers are easily understood } \\
\text { by students. }\end{array}$ & 3.94 & Good \\
\hline $\begin{array}{l}\text { 9. The learning assessment procedure by lecturers can be } \\
\text { accessed by all stakeholders. }\end{array}$ & 3.51 & Good \\
\hline $\begin{array}{l}\text { 10. The results of learning assessments by lecturers can be } \\
\text { accessed by all stakeholders. }\end{array}$ & 3.70 & Good \\
\hline $\begin{array}{l}\text { 11. The lecturer conveys and makes an agreement with } \\
\text { students about the stages, techniques, instruments, } \\
\text { criteria, indicators, and the weight of the assessment at } \\
\text { the beginning of the lecture. }\end{array}$ & 3.99 & Good \\
\hline $\begin{array}{l}\text { 12. The lecturer carries out the assessment process in } \\
\text { accordance with the stages, techniques, instruments, } \\
\text { criteria, indicators, and weight of the assessment agreed } \\
\text { upon at the beginning of the lecture }\end{array}$ & 3.94 & Good \\
\hline $\begin{array}{l}\text { 13. Lecturers provide feedback and opportunities to } \\
\text { question the results of the assessment to students }\end{array}$ & 4.25 & Good \\
\hline $\begin{array}{l}\text { 14. Lecturers show documentation of assessment processes } \\
\text { and student learning outcomes in an accountable and } \\
\text { transparent manner. }\end{array}$ & 4.06 & Good \\
\hline
\end{tabular}

Received December $17^{\text {th }} 2020$, Revision January $27^{\text {th }} 2021$, Accepted for publication February $24^{\text {th }} 2021$. Copyright (C) 2021 Published by FKIP - Unpatti, ISSN 2721-3110 


\begin{tabular}{|c|c|c|}
\hline $\begin{array}{l}\text { 15. Lecturers carry out learning assessments using various } \\
\text { assessment techniques (observation, participation, } \\
\text { performance, written tests, oral tests, and } \\
\text { questionnaires). }\end{array}$ & 4.27 & Very good \\
\hline $\begin{array}{l}\text { 16. Lecturers use process assessment in the form of } \\
\text { portfolios or design work. }\end{array}$ & 4.06 & Good \\
\hline
\end{tabular}

\section{Model Concept to be Developed}

Based on the criteria put forward by Lamont, M. (2007), the use of e-portfolios for learning should aim to help students improve learning and learning through: a) collecting and using learning evidence that critically reflects learning and learning, b) increasing collaboration between participants students with their peers and with lecturers to critically evaluate their progress in learning and learning, c) critically analyze their practice in relation to theory and research, and d) increase learning independence by systematically assessing and setting individual personal professional goals learners. These goals are designed to reflect aspects of learning such as metacognition, critical reflection and collaboration, and incorporate goal setting and self-assessment. In addition, the portfolio for assessment purposes must also be designed to be able to meet the principles of learning assessment in accordance with Permendikbud No. 3 of 2020 concerning the National Higher Education Standards, including: educational, authentic, objective, accountable and transparent which is carried out in an integrated manner.

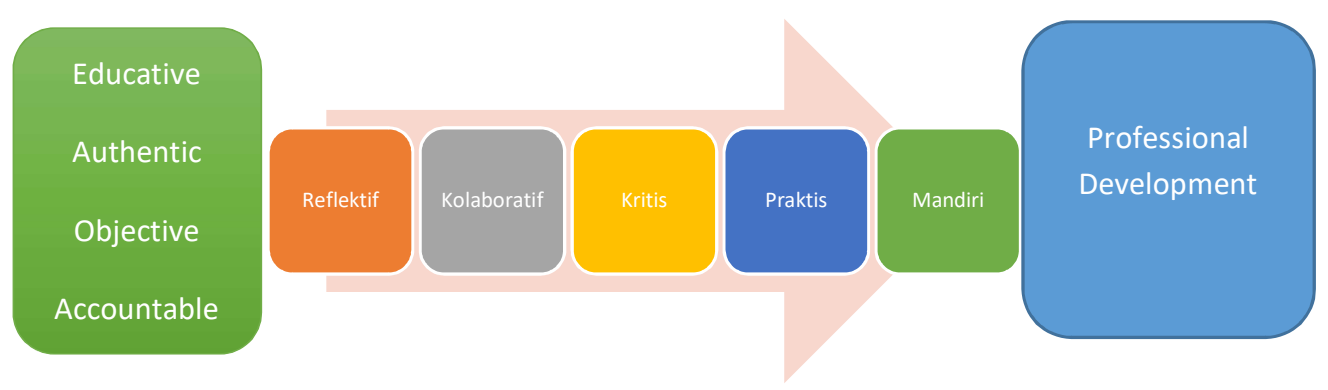

Figure 1. E-Portfolio-Based Authentic Assessment Model

\section{E-Portfolio Platform to be Developed}

At this stage, a field study was also carried out in the form of observation and data collection regarding the gaps in the ongoing assessment model and the availability of facilities and infrastructure and resources that could support the development of an eportfolio-based authentic assessment model. To achieve this goal, interview, questionnaire and observation techniques will be used.

This stage includes an in-depth study of several existing e-portfolio based authentic assessment platforms, namely Elgg, Moodle, and Mahara. Each platform is assessed for its strengths and weaknesses and then it is decided whether the model to be developed. This assessment refers to the six E-portfolio criteria proposed by Brown in Ivers (2019) including: a) kstorage capacity, b) collaboration opportunities, c) ease of use, d) cost, e) availability of support, and f) attractiveness. 
Edu Sciences J. Vol. 2, No. 1. March 2021, 29-37

Table 2. Comparison of the Features of several E-Portfolio Platforms

\begin{tabular}{|c|l|c|c|c|}
\hline \multicolumn{2}{|c|}{ Aspect } & Elgg & Moodle & Mahara \\
\hline 1 & Storage Capacity & 4.10 & 3.22 & 3.97 \\
\hline 2 & Collaboration Opportunities & 3.85 & 3.14 & 4.35 \\
\hline 3 & Ease of Use & 4.10 & 3.25 & 4.10 \\
\hline 4 & Cost & 3.75 & 4.30 & 4.50 \\
\hline 5 & Availability of support & 4.29 & 3.50 & 4.27 \\
\hline 6 & Attractiveness & 4.04 & 3.75 & 3.85 \\
\hline \multicolumn{2}{|l|}{ Average } & 4.02 & 3.53 & 4.17 \\
\hline
\end{tabular}

Based on The comparison results with the E-Portfolio platforms above, then in this study the E-Portfolio Platform which will be used for the E-Portfolio-Based Authentic Assessment Model for the Learning Media Development Course is Mahara which based on the results of the assessment has several advantages compared to that others, covering aspects of $\mathrm{k}$ storage capacity, collaboration opportunities, ease of use, and cost.

Use of E-Portfolio as an assessment instrument in co-curricular; study programs play an important role in achieving future employment opportunities, where students are encouraged to produce authentic evidence of their performance at the best value. This is why they hope to learn in a manner that conforms to a form of assessment that can actually measure their ability authentically. Therefore, learning practices such as project learning and reflective thinking can become goals of higher education where student performance is not only assessed in the form of standard performance tests that are generally conducted.

E-Portfolios not only assess student performance, but also lecturer performance over time related to the effectiveness of strategies and media, and the tools used in learning. Several research results, including research by Ivanova, OV (2017), Alajmi, MM (2019), Dray, K., \& Howells, K. (2019), found that learning and assessment using e-portfolios can: (1) Encourage students who articulate their learning and self-development goals, (2) incorporate self-monitoring and self-assessment of their learning progress and guide them for self-reflection, (3) provide feedback and encourage the use of feedback to inform students' future goals, (4) encourage students to articulate appropriate strategies to achieve their goals,

\section{Conclusion}

The importance of an authentic assessment model that is fair and objective and based on the performance of students and can reflect their potential through the evidence presented in this e-portfolio is a strong reason to develop an e-portfolio based authentic assessment model for PNFI Learning Media Development courses in the the Non-formal Education Study Program, Faculty of Teacher Training and Education, Universitas Pattimura. The Mahara Platform is a suitable platform to be used in the learning process. The results of this study recommend that an authentic assessment model be developed based on the model produced at the research needs analysis stage through: a) collection and use of learning evidence that critically reflects learning and learning, b) enhancing collaboration between students and their peers and with lecturers to critically evaluate their progress in learning and learning, c) critically analyzing their practice in relation to theory and research, and d) increasing learning independence by systematically assessing and setting personal professional goals of each learner.

Received December $17^{\text {th }} 2020$, Revision January $27^{\text {th }} 2021$, Accepted for publication February $24^{\text {th }} 2021$. Copyright (C) 2021 Published by FKIP - Unpatti, ISSN 2721-3110 


\section{REFERENCES}

Alajmi, MM (2019). The impact of E-portfolio use on the development of professional standards and life skills of students: A case study. Entrepreneurship and Sustainability Issues, 6 (4), 1714-1735.

Beck, Lisa M. and Hatch, Thomas, in Clauss-Ehlers, Caroline S. (Ed), Encyclopedia of Cross-Cultural School Psychology, New York: Springer, 2010.

Brady and Kennedy, In Berry, Rita, Assessment for Learning, Hong Kong: Hongkong University Press, 2008.

Buyarski, Catherine A. and Landis, Cynthia M., "Using an ePortfolio to Assess the Outcomes of a First-Year Seminar: Student Narrative and Authentic Assessment", International Journal of ePortfolio, 2014, 4 (1) pp. 49-60 .

Buzzetto-More, Nicole (Ed), The E-portfolio Paradigm: Informing, Educating, Assessing, and Managing with E-Portfolios, California: informing Science Press, 2010.

Buzzetto-More, Nicole (Ed), The E-portfolio Paradigm: Informing, Educating, Assessing, and Managing with E-Portfolios, California: informing Science Press, 2010.

Dray, K., \& Howells, K. (2019). Exploring the Use of E-Portfolios in Higher Education Coaching Programs. International Sport Coaching Journal, 6 (3), 359-365.

Hsieh Pel-Hsuan, Lee, Chun-I, and Chen, Wei-Fan, "Students 'Perspectives on E-portfolio Development and Implementation: A Case Study in Taiwanese Higher Education" Australasian Journal of Educational Technology', 2015, 31 (6 )

Ivanova, OV (2017), Alajmi, MM (2019), Dray, K., \& Howells, K. (2019).

Ivanova, OV (2017). The use of e-portfolio to develop English language learners' autonomy and independence. Інформаційні технології і засоби навчання, (60, вип. 4), 155165.

Jeffrey K Smith ,. in van Schalkwyk, Gertina J. and D'Amato, Rik Carl (Eds),From the Confucian Way to Collaborative Knowledge Co-Construction, Bloomington, Indiana: Xlibris,2012.

Johnson, Elaine B., Contextual Teaching and Learning: What It Is and Why It's Here To Stay, California: Corwin Press Inc: 2002.

Jones, Marianne and Shelton, Marilyn, Developing Your Portfolio: Enhancing Your Learning and Showing Your Stuff: a Guide for The Early Childhood Student or Professional, 2nd ed. New York: Taylor and Francis, 2011.

Karen S. Ivers. (2020) Using technology to support high-impact educational practices. California: ABC-CLIO

Lamont, M. (2007). What are the features of e-portfolio implementation that can enhance learning and promote self-regulation. European Institute for E-Learning (EIfEL), 32.

Rassin et al. in Timmins, Fiona, Making Sense of Portfolios: a Guide for Nursing Students, New York: McGraw Hill, 2008.

Received December $17^{\text {th }} 2020$, Revision January $27^{\text {th }} 2021$, Accepted for publication February $24^{\text {th }} 2021$.

Copyright (C) 2021 Published by FKIP - Unpatti, ISSN 2721-3110 
Russel, Michael K. and Airaisian, Peter W., Classroom Assessment, 7th ed, New York: McGraw Hill, 2012.

Russell III, William B., Waters, Stewart, and Turner, Thomas N., Essentials of Middle and Secondary Social Studies, New York: Taylor and Francis, 2014.

Yan, Sufeng, Song, Runjuan, and Sun, Liming in Luo, Jia (Ed), Affective Computing and Intelligent Interaction, Berlin: Springer, 2012.

Received December $17^{\text {th }} 2020$, Revision January $27^{\text {th }} 2021$, Accepted for publication February $24^{\text {th }} 2021$.

Copyright (C) 2021 Published by FKIP - Unpatti, ISSN 2721-3110 